\title{
Applying an integrated approach to social media communication training: how innovative thinking is changing the way universities teach (Web) journalism
}

\author{
Ainara Larrondo-Ureta, Simón Peña-Fernández, Koldo Meso-Ayerdi, Jesús Pérez- \\ Dasilva \\ Journalism II, University of the Basque Country, Spain.
}

\begin{abstract}
This paper focuses on the challenges of teaching Internet-based communications, an inherently difficult task given the rapid pace of technological innovation in the discipline. The analysis it offers has been based on the findings of empirical studies conducted over the past five years by KZBerri, a University of the Basque Country-based research group focused on teaching innovation in Web journalism courses that form part of the curricula of the school's undergraduate journalism, audiovisual communication, and advertising and public relations degree programmes. The authors highlight two online journalism teaching innovation initiatives, one entailing a collaboration between students and media professionals, and the other entailing online collaboration between groups of students pursuing undergraduate communication degrees at universities located in Spain, Portugal and Brazil.
\end{abstract}

Keywords: teaching; innovation; university; journalism; transmedia; online collaboration 


\section{Introduction}

Over the past few decades, the University of the Basque Country (UPV/EHU) has made a concerted effort to exploit the potential of technology in general and Internet technology in particular to enhance the educational programmes it offers. Professors in every department have striven to update curricula by making innovative Internet-based tools such as blogs, websites and social media an integral part of the teaching-learning process. This is in keeping with a general trend: more and more educators are using social media tools to refine their teaching approaches and boost student engagement and interaction (Cochrane, 2014). The user-friendly characteristics and free access policies of many blogging platforms and the opportunities these sites provide to produce content integrating text, images and sound have made blogging one of the most frequently employed and studied forms of Web-based technology in the sphere of education. University journalism programmes have given blogging an increasingly important role in undergraduate courses on the basis of research findings confirming its value as a tool for acquiring digital and online skills.

It is widely acknowledged that the future of the fields of journalism and communication hinges tightly on their ability to embrace technological innovation and consolidate professional practices for Web-based media. This paper explores recent approaches to teaching these disciplines that have fostered the fuller integration of techniques related to multimedia convergence and social media communication into university curricula (Carrie \& Kraeplin, 2003; Tarcia \& Marinho, 2008). The initiatives described here have been based on the assumption that training in convergent media (multimedia, transmedia, cross-media, etc.) and journalism 2.0 will continue to form a relevant part of university communication curricula for decades to come (Bhuiyan, 2010; Cochrane, 2014).

In light of this prospect, this paper highlights two successful teaching initiatives in which the research group KZBerri has played a role: the first of which was a collaboration between the University of the Basque Country's master's programme in communication and the Basque public television network during which graduate students produced transmedia content hand-in-hand with professional journalists and the second an international, multimedia, collaborative teaching project linked to Online Newswriting, a course that all second-year communication students at that university are required to take. Although Online Newswriting and other courses devoted to online and multimedia communication currently being offered at the University of the Basque Country reflect a decade of teaching innovation that began with the implementation of the European Higher Education Area, their cutting edge nature has supposed the need to review and update them on a periodic basis to ensure they keep pace with ongoing changes in sector technology and practices. 
In fact, courses on Web journalism focusing on news writing can be effective vehicles for teaching the journalistic applications of social media and how media convergence has changed the manner in which journalists carry out their work. These two issues have long formed the crux of questions raised concerning how university journalism curricula should be structured and what material they should cover (Bhuiyan, 2010; Bor, 2014; Scott, 2002).

Keeping in mind the ways in which the professional profiles and skills of online journalists are evolving, this paper also explores key topics that Web journalism curricula should now address, from media convergence and forms of multiplatform communication that employ social media, multiple narratives, etc. to the emergence of a new culture of work that requires individuals to demonstrate a high level of flexibility and strong multi-tasking and collaboration skills on a daily basis. Universities need to address current workplace realities, and Web journalism courses offer an effective means of ensuring that media convergence and journalism 2.0 are covered in communication curricula (Larrondo \& Peña, 2018)..

\section{Web journalism training at the university level: the evolution of teaching approaches in the context of multimedia convergence and communication 2.0}

Since the emergence of online media in the mid-1900s, the profession of Web-based journalism has been immersed in an ongoing process of evolution driven by technological innovation. Experts have pointed to the need to align the content of (Web) journalism courses and approaches to teaching this subject more closely with the roles students will eventually be expected to assume in a sector marked by rapid technological change (Deuze, 2001).

The multiplatform technology that has emerged in tandem with connected devices and social media has added new dimensions to the journalistic profession and drawn researchers' attention to the subject of online journalism. Practically all news companies operating today are engaged in one form or another of technological conversion in the wake of media convergence, transmedia storytelling and data-journalism. Each may be charting out an individualised roadmap based on specific cultural and financial considerations and a specific business strategy, but all are looking for journalists prepared to flexible on the job who thrive in collaborative environments and are capable of producing content in various media.

When educators began to teach online journalism, writing for online media was their primary concern. What followed was a tendency to apply teaching approaches that had worked for print journalism to its online counterpart while attempting to address the novel hypertextual, multimedia and interactive aspects of new media as well. Over time it became clear that online communication professionals needed certain skills that journalism degree 
programmes weren't providing. As one scholar observed, "employers are requesting that applicants possess skills in web content creation, multiplatform adaptability and social media, while theoretical knowledge and basic writing and communication skills remain top requirement” (Bor, 2014).

Innovation in both professional Web journalism and academic research on that specialised field has since prompted educators to reconsider current teaching practices and ask themselves: what type of training do future online journalists need in order to practice their profession in a constantly changing environment in which they are expected to multi-task, collaborate with others and produce multimedia content on a daily basis? It is reasonable to assume that students wishing to enter the field must learn to distinguish between the differing possibilities for constructing multiple narratives that hypermedia, multimedia, multiplatform and transmedia offer. Storytelling options currently open to web journalists fall into four basic categories:

a) Hypermedia and multimedia Internet-based stories. Both of these options permit a journalist to use various means of expression (writing, video, audio and graphics) to construct a story - the first in the form of juxtapositions and combinations supported by links and the latter in a more integrated fashion made possible by dynamic programming languages.

b) Single media textual, audio, video or photo gallery stories created for online distribution that can be adapted as desired for multiplatform or cross-media use, common combinations of delivery channels being television and the Web, radio and the Web or a print publication and the Web. Multiplatform distribution decisions are made after content has been produced.

c) Stories envisioned as multiplatform content from the outset. This type of content calls for teamwork, takes more time to execute and requires sufficient prior planning and understanding of the narrative possibilities and limits of each medium involved in order to ensure that the end product is suitable for every medium envisaged.

Journalism has been enmeshed in a decades-long process of reinvention that has centred on using new digital tools to deliver news and information in a more compelling and effective way. Job profiles in the sector have evolved as a result. Journalists are now forging careers as multimedia content development managers and digital storytelling specialists, particularly in the area of visual communication. Although there are always exceptions to the rule, most journalism enterprises are pursuing corporate or newsroom convergence projects that involve journalists working in different media to coordinate their coverage or enable a wide range of professionals to form multidisciplinary teams with the capacity to produce content for more than one medium. 
d) Transmedia stories and reports, the most innovative option open to online journalists today. Transmedia journalism employs a variety of media to tell a single, composite story. The power social media users have to extend and enrich narratives through interaction and participation makes audience engagement a crucial aspect of this approach (Jenkins, 2003). Transmedia production allows journalists to use every medium employed to its best advantage and explore different facets of a story in a wide variety of ways (viral videos, webdocs, special reports, radio and television programmes, tweets, posts, etc.).

\section{Innovative approaches to teaching online journalism}

\subsection{Transmedia narrative}

In line with the goal of helping students become well-rounded communicators, journalism training at the university level needs to stress the importance of adopting a positive attitude towards teamwork, multitasking and collaboration with other professionals. In this regards, despite the efforts media organisations have made to restructure their newsrooms to suit current circumstances, they continue to grapple with the fact that content production in innovative formats such as transmedia requires longer production time frames, greater resources and special skills related to social media 2.0 communication -capacity to connect with audiences in a manner that fosters engagement and the viralization of content. Transmedia content production also requires a high level of coordination and the involvement of professionals who know what works best in a range of media (Jenkins, 2003; Pratten, 2011).

Universities have responded to the dilemmas facing the sector by developing innovative new courses that help students gain hands-on professional experience, develop the social media and teamwork skills they need to secure entry level Web journalism positions and thrive in multimedia, interactive and digital environments. Some institutions of higher learning have also developed research groups focused on the challenges confronting the sector today or training programmes for working professionals interested in expanding their knowledge of multimedia journalism. Some of the more outstanding initiatives in this area include Integrated Journalism in Europe, an interdisciplinary project being carried out by five European universities; and the Knight Digital Media Center, aimed at helping journalists and other communications professionals strengthen their digital news production skills.

Other projects focus on the development of teaching techniques that are subsequently tested in what are referred to as 'media labs.' Outstanding initiatives in this category include Harvard's Nieman Journalism Lab, the Massachusetts Institute of Technology's Media Lab and Open Documentary Lab, the MMLab developed by the University of the Basque 
Country in the context of its master's programme in multimedia communication, amongst other. Periodic and on-demand courses and training modules provided by Google News Lab also help reduce the digital knowledge gap plaguing the sector.

Universities are increasingly placing a heavy focus on transmedia training. Students enrolled in the News21, a communications programme funded by the Carnegie Corporation and the Knight Foundation, for example, were required to produce web-based multimedia documentary content. The University of the Basque Country's master in communication programme also covers students' multiplatform and multimedia production.

Students enrolled in this master's programme have participated in the last decade in KulturLab initiative, an annual week-long event held in a different location each year during which future professional communicators have the chance to create multimedia and transmedia projects focusing on some of Europe's most exciting cities. Specifically, the 2012-2013 collaboration between this master's programme and the Basque public broadcaster EITB gave KulturLab students the opportunity to provide 'docu-reality' and transmedia coverage of the Korrika, an multi-day foot race organised in the Basque Country every other year to raise funds for AEK, an organisation devoted to the teaching and promotion of the Basque language. KulturLab students produced viral videos, TV reports, television and radio programmes and 'twittersodes' related to this event. Initiatives such as KulturLab, which has generated highly positive feedback from students and faculty members alike, reflect a general shift towards post-graduate teaching approaches providing a balanced mix of theory, multimedia techniques and practices, and hands-on experience.

Students must become familiar with an ample range of social media platforms, learn to use in-house content to create online communities and ensure user loyalty and develop the skills they need to become adept community managers. Gone are the days when media enterprises dove headfirst into social media without a road map. Any media enterprise today with the budget to do so has a well-planned social media strategy. Larger organisations such as the BBC, Reuters and The Washington Post have even issued internal journalism 2.0 style guides.

\subsection{Internationalization at home and online collaboration}

Throughout the current academic year, KZBerri has been actively engaged in a UPV/EHUfunded international teaching innovation project titled "Virtual Collaborative Learning in Online Newswriting: A Brazilian-Portuguese-Basque Experience”. During this time, researchers distributed survey questionnaires to students and professors presently involved in the course, organised face-to-face and virtual discussion sessions with these two groups and conducted ethnographic observation sessions in classrooms to assess the effectiveness of teaching strategies applied in the multimedia and transmedia aspects of Online Newswriting, a course that all students enrolled in undergraduate degree programmes in 
journalism, advertising and public relations and audio visual communication at the University of the Basque Country are required to take.

The first phase of this international initiative, titled "Cooperative Learning in Online Newswriting through Web 2.0: a Brazilian-Basque Experience”, was a collaboration between UPV/EHU and a university located in Brazil that ran from February 2017 through December 2018. The second, which began in February 2018 and will terminate in December 2019, involves two new partner universities, both of which are located in Portugal.

During the current phase of the project, online work teams composed of students from the various universities involved (The Federal Universities of Mato Grosso do Sul and Piauí in Brazil, the Universities of Oporto and Covilha in Portugal and the University of the Basque Country in Spain) have been required to carry out joint multimedia assignments. The collaborative framework and content of the initiative has been based on the classroom experience and research of a pro-active team of professors with a firm commitment to the field of Web journalism based in three different countries: Juliana Fernandes Teixeira and Gerson Luis Santos (Brazil), Joao Canavilhas and Fernando Zamith (Portugal) and Koldo Meso, Jesús Ángel Pérez and Ainara Larrondo (Spain).

This project, which seeks to give students a more active role in their individual learning processes and academic development, has been designed to take the high engagement levels of digital natives into account. Like other programmes of this type, it uses internationalisation at home strategies (which in this case take the form of joint Web-based reporting assignments) that foster bilingualism (the working language selected for phase two being English), to bring students into contact with peers in other countries and allow them to hone their online collaboration skills. Other facets of the programme such as virtual and classroom peer critique sessions and the exposure of Web-based class projects to a broader online audience encourage students to learn from the opinions of others and become better listeners, habits that will serve them well in their future careers as online journalists.

\section{Final remarks}

Studies conducted to date on the impact of media convergence indicate that most news enterprises and organisations, regardless of their size and other characteristics, continue to suffer setbacks related to the difficulty of shifting from a single media to a multimedia work culture. This evidence of their lingering inability to fully adapt to new modes of production underscores the need for a deeper examination of the professional challenges multimedia and multiplatform content production entails and how these problems might be addressed through new approaches to journalism training. 
Teaching students how to create content in the traditional story formats of journalism (news, feature, interpretative, etc.) has long been the thrust of university news writing courses. Online Newswriting, the Web journalism course offered at the University of the Basque Country highlighted in this paper, was structured along these lines until quite recently. Research findings and industry feedback nevertheless indicate that this narrow approach falls short of the mark in the age of Internet technology. Young people aspiring to forge careers as news professionals must acquire other generic and cross-disciplinary competences as well in order to thrive in Journalism 2.0 and media convergent environments in which they will be called upon to demonstrate the teamworking skills required in online and offline collaboration and the production of transmedia content.

Due to the pace of technological innovation in their area of specialisation and the wide variety of formats in which they work, online media journalists are under greater pressure than their peers in print and audiovisual media to be cross-disciplinary multi-taskers and efficient team workers - roles of particular importance in the production of multimedia content.

\section{References}

Bhuiyan, S. I. (2010). “Teaching media convergence and its challenges”. Asia Pacific Media Educator, 20.

Bor, S. E. (2014). “Teaching Social Media Journalism: Challenges and Opportunities for Future Curriculum Design”. Journalism \& Mass Communication Educator, 69(3), 243255.

Carrie A. C, \& Kraeplin, C. (2003). "The State of Convergence Journalism: United States Media and University Study”. Proceedings of the AEJMC Annual Convention, Kansas City, MO.

Cochrane, Thomas. (2014). "Critical success factors for transforming pedagogy with mobile web 2.0”. British Journal of Educational Technology, 45(1): 65-82.

Deuze, Mark (2001). "Educating 'New' Journalists: Challenges to the Curriculum”. Journalism \& Mass Communication Educator 56, 4-17.

Jenkins, H. (2003). "Transmedia Storytelling", MIT Technology Review. http://www.technologyreview.com/news/401760/transmedia-storytelling

Larrondo, A.; Peña, Simón (2018). “Keeping pace with journalism training in the age of social media and convergence: How worthwhile is it to teach online skills?” Journalism, print ahead December 4, 2017.

Pratten, R. (2011). Getting started in Transmedia Storytelling. A practical guide for beginners.

Tarcia, L. \& Marinho, S. P. (2008). “Challenges and New Ways of Teaching Journalism in Times of Media Convergence”, Brazilian Journalism Research, 4, 2, semester 2, 25-53. 